\title{
Survival of Coronaviruses in Water and Wastewater
}

\author{
Patricia M. Gundy · Charles P. Gerba • \\ Ian L. Pepper
}

Received: 1 October 2008/Accepted: 13 November 2008/Published online: 3 December 2008

(C) Springer Science+Business Media, LLC 2008

\begin{abstract}
The advent of severe acute respiratory syndrome and its potential environmental transmission indicates the need for more information on the survival of coronavirus in water and wastewater. The survival of representative coronaviruses, feline infectious peritonitis virus, and human coronavirus $229 \mathrm{E}$ was determined in filtered and unfiltered tap water $\left(4\right.$ and $\left.23^{\circ} \mathrm{C}\right)$ and wastewater $\left(23^{\circ} \mathrm{C}\right)$. This was compared to poliovirus 1 under the same test conditions. Inactivation of coronaviruses in the test water was highly dependent on temperature, level of organic matter, and presence of antagonistic bacteria. The time required for the virus titer to decrease $99.9 \%\left(\mathrm{~T}_{99.9}\right)$ shows that in tap water, coronaviruses are inactivated faster in water at $23^{\circ} \mathrm{C}$ (10 days) than in water at $4{ }^{\circ} \mathrm{C}$ ( $>100$ days). Coronaviruses die off rapidly in wastewater, with $\mathrm{T}_{99.9}$ values of between 2 and 4 days. Poliovirus survived longer than coronaviruses in all test waters, except the $4^{\circ} \mathrm{C}$ tap water.
\end{abstract}

Keywords Survival - Water - Wastewater - Coronavirus . SARS

\section{Introduction}

The 2003 epidemic of severe acute respiratory syndrome (SARS) resulted in over 8,000 cases worldwide with a mortality rate of approximately 10\% (Manocha et al. 2003; Centers for Disease Control 2004). The last known

P. M. Gundy $(\bowtie)$ C C. P. Gerba · I. L. Pepper

Department of Soil, Water and Environmental Science,

University of Arizona, 1177 E. 4th St. Room 429,

P.O. Box 210038, Tucson, AZ 85721, USA

e-mail: pgundy@ag.arizona.edu outbreak occurred in a research lab in Beijing in 2004. The cause of this disease was identified as a novel human coronavirus with probable origins in civets and a possible reservoir in bats (Guan et al. 2003; Lau et al. 2005; Wang et al. 2006). Coronaviruses are enveloped, single-stranded RNA viruses that range from 60 to $220 \mathrm{~nm}$ in size. They can infect birds and mammals, including humans, and are transmitted through aerosols or the fecal-oral route. The rapid spread of coronaviruses during outbreaks suggests the primary mode of transmission of human coronaviruses is respiratory droplets; however, there is no direct evidence to support this (Belshe 1984). Since coronavirus infection in humans up to this point has been characterized as a mild, self-limiting condition, there is limited information on its transmission potential through the environment.

The SARS epidemic had potential links to water and wastewater given that the March 2003 outbreak at the highrise housing estate in Hong Kong involving over 300 people was linked to a faulty sewage system (Peiris et al. 2003). The fact that SARS-CoV can replicate in the enteric tract (Leung et al. 2003) makes it a possible enteric pathogen, and the incidence of diarrhea ranging from 8 to $73 \%$ in SARS cases (SARS Epidemiology Working Group 2003) causes concern about its potential environmental transmission. Leung et al. (2003) also reported that viral cultures from SARS patients recovered higher yields from the small intestine than the lung tissues, which are the target organs of this virus. Infectious virus has been cultured from stools of SARS patients up to 3 weeks post infection (Chan et al. 2004; Liu et al. 2004). The advent of SARS and the question of its transmission indicate the need for more information, specifically the survival of coronavirus in water and wastewater. This study compared the survival of representative coronaviruses and poliovirus 1 in tap water and wastewater. 


\section{Materials and Methods}

Feline infectious peritonitis virus (FIPV) (ATCC-990), an enteric feline coronavirus, was propagated and assayed in the Crandell Reese feline kidney cell line (CRFK) (ATCC94). Human coronavirus 229E (HCoV) (ATCC-740), a respiratory virus, was propagated and assayed in the fetal human lung fibroblast, MRC-5 cell line (ATCC-171). Poliovirus 1 LSc-2ab (PV-1), a human enteric virus known to be very stable in the environment, was propagated and assayed in the Buffalo green monkey kidney (BGM) cell line. Infected cells were frozen and thawed three times at $-20^{\circ} \mathrm{C}$ to release virus after cytopathogenic effects (CPE) were observed in the monolayer. This was followed by centrifugation at $1000 \mathrm{~g}$ for $10 \mathrm{~min}$ to remove cell debris, addition to the virus suspension of $9 \%$ polyethylene glycol (MW 8000) and $0.5 \mathrm{M}$ sodium chloride, and stirring overnight at $4^{\circ} \mathrm{C}$. After centrifugation at $10,000 \mathrm{~g}$ for $30 \mathrm{~min}$, the pellet was resuspended in $0.01 \mathrm{M}$ phosphate buffered saline (PBS; pH 7.4) (Sigma, St. Louis, MO) to $5 \%$ of the original virus suspension volume. The coronaviruses were then titered and stored at $-80^{\circ} \mathrm{C}$. The poliovirus was further purified by extraction with equal volumes of Vertrel XF (Dupont, Wilmington, DE), emulsified and centrifuged at $7,500 \mathrm{~g}$ for $15 \mathrm{~min}$, and subsequently the top aqueous layer was collected, titered, and stored at $-80^{\circ} \mathrm{C}$.

Tap water samples were collected from a cold tap faucet in the laboratory. The source is groundwater with water quality parameters: $\mathrm{pH}$ 7.8, $297 \mathrm{mg} / \mathrm{l}$ dissolved solids, and $0.1 \mathrm{mg} / \mathrm{l}$ total organic carbon. The water was allowed to run for $3 \mathrm{~min}$ before collection of the sample. Virus survival was determined in both nonfiltered tap water and tap water passed through a $0.2-\mu \mathrm{m}$ pore size filter to remove bacteria. Tap water $(30 \mathrm{ml})$ was added to sterile $50 \mathrm{ml}$ polypropylene centrifuge tubes, to reduce loss of virus by adhesion to the container. Sterile sodium thiosulfate was added to a final concentration of $33 \mu \mathrm{g} / \mathrm{ml}$ to dechlorinate the water. After vortexing, virus was added to each tube to a final concentration of $10^{5} \mathrm{TCID}_{50} / \mathrm{ml}$. Again the tubes were vortexed and a sample was immediately taken (zero time point). The tubes of tap water were then stored at either $4^{\circ} \mathrm{C}$ or room temperature $\left(23^{\circ} \mathrm{C}\right)$. The tubes stored at room temperature were covered in aluminum foil to prevent exposure to light. Tubes were sampled after $1,3,6$, 10,15 , and 21 days and the samples frozen at $-80^{\circ} \mathrm{C}$ until they were assayed on cells.

Samples of primary and activated sludge (secondary) effluent were collected in sterile polypropylene bottles from the Roger Road Wastewater Treatment Plant in Tucson, AZ, USA. Primary effluent was collected after settling and secondary effluent was collected prior to chlorination. Typical wastewater quality parameters for this facilities primary effluent are biological oxygen demand (BOD) and suspended solids of $110-220 \mathrm{mg} / \mathrm{l}$. Secondary effluent at Roger Road typically reflects a 90 95\% reduction in both BOD and suspended solids from the primary effluent. The effluent $(30 \mathrm{ml})$ was added to sterile $50 \mathrm{ml}$ polypropylene centrifuge tubes. Primary effluent was filtered through a $0.2-\mu \mathrm{m}$ pore size filter before addition of the virus and was also tested unfiltered. Secondary effluent was only tested unfiltered. Virus was then added to each tube to a final concentration of $10^{5} \mathrm{TCID}_{50} / \mathrm{ml}$. The tubes were vortexed and a sample was immediately taken (time zero). The tubes were then covered and held at room temperature $\left(23^{\circ} \mathrm{C}\right)$. Samples were collected after 1, 2, 3, 6, 10,15 , and 21 days and the samples frozen at $-80^{\circ} \mathrm{C}$ until assay.

Viruses were enumerated on cell cultures using either the plaque assay or $\mathrm{TCID}_{50}$ technique. PV-1 was titered in 6-well plastic cell culture plates by the plaque assay method (Payment and Trudel 1993). This is a direct quantitative method with a minimum detection limit of $10 \mathrm{pfu} / \mathrm{ml}$. Each dilution was plated in duplicate wells. Coronaviruses, which do not form plaques in cell culture, were titered in 24-well plastic cell culture plates by the tissue culture infectious dose $50 \%$ technique $\left(\mathrm{TCID}_{50}\right)$ (Payment and Trudel 1993). This technique determines the dilution at which $50 \%$ of the wells show CPE. Taking the inverse $\log$ of this dilution gives a titer of the virus per $\mathrm{ml}$ TCID $_{50}$. The minimum detection for this method was 3.7 viruses per ml. Each dilution was plated in a minimum of 8 wells. Any samples that were not from test waters filtered prior to adding virus had to be filtered before assaying on cell culture to eliminate bacterial contamination. The $0.2 \mu \mathrm{m}$ low protein binding Millex filters (Millipore, Billerica, MA) with polyethersulfone (PES) membrane were prepared by passing 3\% beef extract (Becton Dickinson, Sparks, MD) at $\mathrm{pH} 7$ through to block sites that might adsorb virus. All experiments were performed in triplicate.

\section{Results and Discussion}

Table 1 shows the survival in days of the three viruses in the test waters. The log reduction of each virus was calculated by the formula " $\log _{10} N / N_{0}$ " where $N$ is the titer of the virus at the specified day and $N_{0}$ is the virus titer at time 0 . The slope of the linear regression was used to determine the survival; the time required for the virus titer to decrease 99\% and $99.9 \%$ (expressed as $\mathrm{T}_{99}$ and $\mathrm{T}_{99.9}$ respectively).

Factors that can influence virus survival in water include temperature, organic matter, and aerobic microorganisms (John and Rose 2005; Melnick and Gerba 1980; Sobsey and Meschke 2003). The most critical influence on virus 
Table 1 Survival in days ${ }^{\mathrm{a}}$ of study viruses ${ }^{\mathrm{b}}$ in tap water and wastewater

\begin{tabular}{|c|c|c|c|c|c|c|c|c|c|c|c|c|}
\hline \multirow[t]{2}{*}{ Virus } & \multicolumn{2}{|c|}{$\begin{array}{l}\text { Tap water } \\
\text { filtered } 23^{\circ} \mathrm{C}\end{array}$} & \multicolumn{2}{|c|}{$\begin{array}{l}\text { Tap water } \\
\text { unfiltered } 23^{\circ} \mathrm{C}\end{array}$} & \multicolumn{2}{|c|}{$\begin{array}{l}\text { Tap water } \\
\text { filtered } 4^{\circ} \mathrm{C}^{\mathrm{c}}\end{array}$} & \multicolumn{2}{|c|}{$\begin{array}{l}\text { Primary effluent } \\
\text { filtered } 23^{\circ} \mathrm{C}\end{array}$} & \multicolumn{2}{|c|}{$\begin{array}{l}\text { Primary effluent } \\
\text { unfiltered } 23^{\circ} \mathrm{C}\end{array}$} & \multicolumn{2}{|c|}{$\begin{array}{l}\text { Secondary } \\
\text { effluent }\end{array}$} \\
\hline & $\mathrm{T}_{99}$ & $\mathrm{~T}_{99.9}$ & $\mathrm{~T}_{99}$ & $\mathrm{~T}_{99.9}$ & $\mathrm{~T}_{99}$ & $\mathrm{~T}_{99.9}$ & $\mathrm{~T}_{99}$ & $\mathrm{~T}_{99.9}$ & $\mathrm{~T}_{99}$ & $\mathrm{~T}_{99.9}$ & $\mathrm{~T}_{99}$ & $\mathrm{~T}_{99.9}$ \\
\hline $\mathrm{HCoV}$ & 6.76 & 10.1 & 8.09 & 12.1 & $392^{\mathrm{d}}$ & $588^{\mathrm{d}}$ & 1.57 & 2.35 & 2.36 & 3.54 & 1.85 & 2.77 \\
\hline FIPV & 6.76 & 10.1 & 8.32 & 12.5 & $87.0^{\mathrm{d}}$ & $130^{\mathrm{d}}$ & 1.60 & 2.40 & 1.71 & 2.56 & 1.62 & 2.42 \\
\hline PV-1 & $43.3^{\mathrm{d}}$ & $64.9^{\mathrm{d}}$ & $47.5^{\mathrm{d}}$ & $71.3^{\mathrm{d}}$ & $135^{\mathrm{d}}$ & $203^{d}$ & $23.6^{\mathrm{d}}$ & $35.5^{\mathrm{d}}$ & 7.27 & 10.9 & 3.83 & 5.74 \\
\hline
\end{tabular}

${ }^{a}$ The slope of the linear regression was used to determine the survival; the time, in days, for the virus titer to decrease $99 \%$ and $99.9 \%$, expressed as $\mathrm{T}_{99}$ and $\mathrm{T}_{99.9}$, respectively

${ }^{\mathrm{b}}$ Human coronavirus 229E (HCoV), feline infectious peritonitis virus (FIPV), poliovirus 1 (PV-1)

${ }^{c} \mathrm{HCoV}$ was unfiltered

${ }^{\mathrm{d}}$ Projected values

survival is temperature. It has been shown that virus survival decreases with increasing temperature, mainly caused by denaturation of proteins and increased activity of extracellular enzymes (Hurst et al. 1980; John and Rose 2005). The results of the tap water study verify that this is the case with coronavirus. By testing filtered tap water, we reduced or eliminated the influence of particulate organic matter and bacteria. At room temperature it required only 10 days to result in a $99.9 \%$ reduction of coronavirus in filtered tap water, while at $4^{\circ} \mathrm{C}$ this level of virus inactivation would require over 100 days. The survival of PV-1 in tap water at $4^{\circ} \mathrm{C}$ was similar to the coronavirus, but at room temperature $\left(23^{\circ} \mathrm{C}\right)$ this virus survived six times longer in both the filtered and unfiltered water. The survival of the three study viruses in tap water at room temperature $\left(23^{\circ} \mathrm{C}\right)$ and $4^{\circ} \mathrm{C}$ are shown in Figs. 1 and 2, respectively. The increase in virus titer over time from the initial titer in the $4^{\circ} \mathrm{C}$ water can be attributed to the

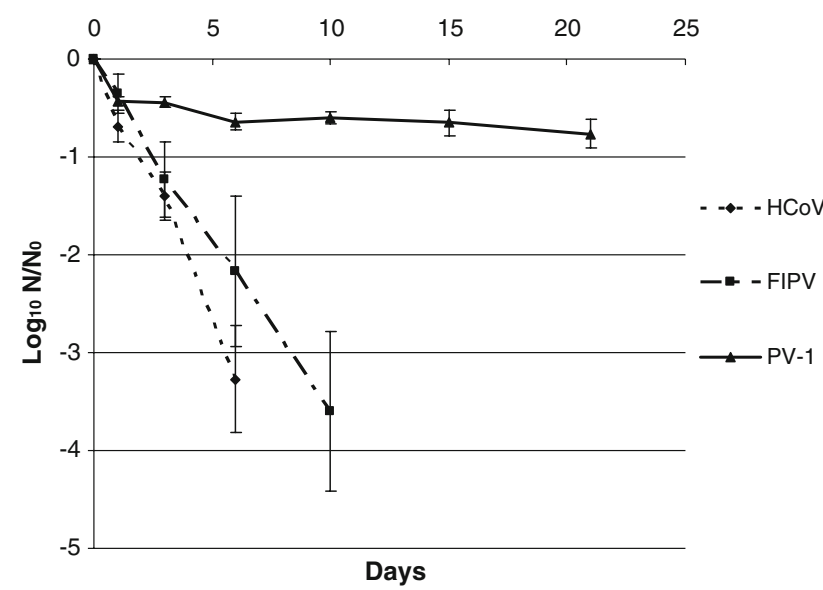

Fig. 1 Average $\log _{10}$ reduction (average $\log _{10} N / N_{0}$ where $N$ is titer of virus at specified day and $N_{0}$ is titer of virus at time 0 ) of study viruses [human coronavirus 229E ( $\mathrm{HCoV})$, feline infectious peritonitis virus (FIPV), poliovirus 1 (PV-1)] in dechlorinated, filtered tap water at room temperature $\left(23^{\circ} \mathrm{C}\right)$

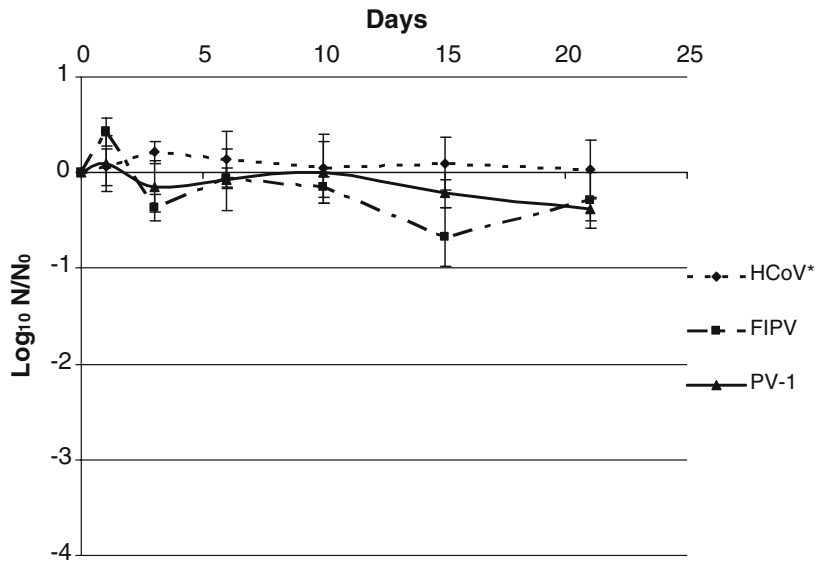

Fig. 2 Average $\log _{10}$ reduction (average $\log _{10} N / N_{0}$ where $N$ is titer of virus at specified day and $N_{0}$ is titer of virus at time 0 ) of study viruses [human coronavirus 229E ( $\mathrm{HCoV})$, feline infectious peritonitis virus (FIPV), poliovirus 1 (PV-1)] in dechlorinated, filtered tap water at $4{ }^{\circ} \mathrm{C}$. *Unfiltered

tendency of viruses to form aggregates that then disaggregate, not from viral replication in the sample.

The presence of organic matter and suspended solids in water can provide protection for viruses that adsorb to these particles but at the same time can be a mechanism for removal of viruses if the solids settle out. The level of organic matter and suspended solids in the test waters increased from tap water to secondary effluent to primary effluent. Coronavirus inactivation was greater in filtered tap water than unfiltered tap water. Furthermore, $\mathrm{HCoV}$ survived longer in unfiltered primary effluent over the filtered. This suggests that higher solids do provide protection for coronaviruses in water. For PV-1, however, filtration made very little difference in its survival in tap water. In the primary effluent, PV-1 survived three times longer in the filtered primary effluent than the unfiltered. It is important to note that there was a substantial decrease in titer of the coronaviruses between the time of addition to the wastewater and the immediate retrieval for testing (zero time 
Table 2 Average $\log _{10}$ reduction $^{\mathrm{a}}$ of study viruses ${ }^{\mathrm{b}}$ in primary effluent and secondary effluent at room temperature $\left(23^{\circ} \mathrm{C}\right)$

\begin{tabular}{|c|c|c|c|c|c|c|c|c|c|}
\hline \multirow[t]{2}{*}{ Day } & \multicolumn{3}{|c|}{ Primary effluent (filtered) } & \multicolumn{3}{|c|}{ Primary effluent (unfiltered) } & \multicolumn{3}{|c|}{ Secondary effluent (unfiltered) } \\
\hline & $\mathrm{HCoV}$ & FIPV & PV-1 & $\mathrm{HCoV}$ & FIPV & PV-1 & $\mathrm{HCoV}$ & FIPV & PV-1 \\
\hline 1 & $>2.0 \pm 0.88$ & $1.7 \pm 1.1$ & $0.04 \pm 0.09$ & $>1.8 \pm 0.54$ & $>1.8 \pm 1.0$ & $0.2 \pm 0.19$ & $1.1 \pm 0.80$ & $1.1 \pm 1.0$ & $0.96 \pm 0.26$ \\
\hline 2 & $>2.9 \pm 0.21$ & $>2.5 \pm 0.62$ & $0.11 \pm 0.17$ & $>2.0 \pm 0.86$ & $>2.7 \pm 0.85$ & $0.54 \pm 0.46$ & $>2.7 \pm 0.54$ & $>2.6 \pm 0.85$ & $1.5 \pm 0.65$ \\
\hline 3 & $>3.4 \pm 0.66$ & $>3.6 \pm 0.17$ & $0.25 \pm 0.24$ & $>2.0 \pm 1.5$ & $>3.1 \pm 0.62$ & $0.69 \pm 0.51$ & $>2.9 \pm 0.80$ & $>3.7 \pm 0.62$ & $2.1 \pm 1.1$ \\
\hline 6 & ND & ND & $0.58 \pm 0.26$ & ND & ND & $1.6 \pm 0.32$ & ND & ND & $3.8 \pm 1.1$ \\
\hline 10 & ND & ND & $1.03 \pm 0.54$ & ND & ND & $2.5 \pm 0.58$ & ND & ND & $4.6 \pm 1.5$ \\
\hline 15 & ND & ND & $1.31 \pm 0.54$ & ND & ND & $4.3 \pm 0.58$ & ND & ND & $3.6 \pm 1.5$ \\
\hline 21 & ND & ND & $1.64 \pm 0.37$ & ND & ND & $4.7 \pm 1.2$ & ND & ND & ND \\
\hline
\end{tabular}

$N D$ not determined

${ }^{\text {a }}$ Average $\log _{10} N / N_{0}$ where $N$ is titer of virus at specified day and $N_{0}$ is titer of virus at time 0 . >indicates that at least one of the triplicates was below detection level of $3.7 / \mathrm{ml} \mathrm{TCID}_{50}$. Values below the detection limit were replaced with the detection limit for the analysis. \pm indicates standard deviation

b Human coronavirus 229E (HCoV), feline infectious peritonitis virus (FIPV), poliovirus 1 (PV-1)

point). The titer of the coronaviruses immediately decreased 99.9\% upon addition to the wastewater, while the PV-1 titer only dropped $10 \%$. This decrease may be due to the presence of solvents and detergents in wastewater that would compromise the viral envelope and ultimately inactivate the virus. This may also indicate that coronaviruses adsorb more readily than PV-1 to solids in the wastewater. The hydrophobicity of the viral envelope makes coronaviruses less soluble in water and could therefore increase the tendency of these viruses to adhere to the solids. Wastewater samples had to be filtered to prevent bacterial contamination of the cell monolayer, which would remove solids and any solids-associated viruses as well.

The presence of predatory microorganisms, such as protozoa, can increase the inactivation rate of virus in water, as well as the action of proteases and nucleases (Gerba et al. 1978; John and Rose 2005). The level of bacteria and solids is both higher in primary effluent compared to secondary effluent. All three test viruses were able to survive longer in the unfiltered primary effluent than the unfiltered secondary effluent, though for FIPV this was negligible. Again, this suggests that solids-associated viruses in wastewater are protected from predation and inactivation. However, the coronaviruses were below the minimum detection limit after 3 days, whereas PV-1 was detectable after 21 days. Results for the average log reduction for the study viruses in wastewater are listed in Table 2.

\section{Conclusion}

The results of this study indicate that coronaviruses are much more sensitive to temperature than PV-1 and that there is a considerable difference in survivability between PV-1 and the coronaviruses in wastewater. This may be due in part to the fact that enveloped viruses are less stable in the environment than nonenveloped viruses. Coronaviruses die off very rapidly in wastewater, with a $99.9 \%$ reduction in 2-3 days, which is comparable to the data on SARS-CoV survival (Wang et al. 2005a, b). Survival of the coronaviruses in primary wastewater was only slightly longer than secondary wastewater, probably due to the higher level of suspended solids that offer protection from inactivation. PV-1 survived substantially longer than coronaviruses, requiring 10 days for a comparable reduction in primary wastewater and 5 days in secondary wastewater. This study demonstrates that the transmission of coronaviruses would be less than enteroviruses in the aqueous environment due to the fact that coronaviruses are more rapidly inactivated in water and wastewater at ambient temperatures.

Acknowledgment This work was supported by a grant from the University of Arizona National Science Foundation Water Quality Center.

\section{References}

Belshe, R. B. (1984). Textbook of human virology. Littleton, MA: PSG Publishing Co, Inc.

Centers for Disease Control. (2004). Severe acute respiratory syndrome fact sheet: Basic information about SARS. Resource document. http://www.cdc.gov/ncidod/sars/factsheet.htm. Accessed 10 November 2008.

Chan, K. H., Poon, L. L. L. M., Cheng, V. C. C., Guan, Y., Hung, I. F. N., Kong, J., et al. (2004). Detection of SARS coronavirus in patients with suspected SARS. Emerging Infectious Diseases, 10, 294-299.

Gerba, C. P., Stagg, C. H., \& Abadie, M. G. (1978). Characterization of sewage-associated viruses in natural waters. Water Research, $12,805-812$.

Guan, Y., Zheng, B. J., He, Y. Q., Liu, X. L., Zhuang, Z. X., Cheung, C. L., et al. (2003). Isolation and characterization of viruses 
related to the SARS coronavirus from animals in Southern China. Science, 302, 276-279.

Hurst, C. J., Gerba, C. P., \& Cech, I. (1980). Effects of environmental variables and soil characteristics on virus survival in soil. Applied and Environmental Microbiology, 40, 1067-1079.

John, D. E., \& Rose, J. B. (2005). Review of factors affecting microbial survival in groundwater. Environmental Science \& Technology, 39(19), 7345-7356.

Lau, S. K. P., Woo, P. C. Y., Li, K. S. M., Huang, Y., Tsoi, H. W., Wong, B. H. L., et al. (2005). Severe acute respiratory syndrome coronavirus-like virus in Chinese horseshoe bats. Proceedings of the National Academy of Sciences of the United States of America, 102(39), 14040-14045.

Leung, W. K., To, K. F., Chan, P. K. S., Chan, H. L. Y., Wu, A. K. L., Lee, N., et al. (2003). Enteric involvement of severe acute respiratory syndrome-associated coronavirus infection. Gastroenterology, 125, 1011-1017.

Liu, W., Tang, F., Fontanet, A., Zhan, L., Zhao, Q. M., Zhang, P. H., et al. (2004). Long term SARS coronavirus excretion from patient cohort, China. Emerging Infectious Diseases, 10(10), 1841-1843.

Manocha, S., Walley, K. R., \& Russell, J. A. (2003). Severe acute respiratory distress syndrome (SARS): A critical care perspective. Critical Care Medicine, 31, 2684-2692.

Melnick, J. L., \& Gerba, C. P. (1980). The ecology of enteric viruses in natural waters. CRC Critical Reviews in Environmental Control, 10, 65-93.
Payment, P., \& Trudel, M. (1993). Methods and techniques in virology. New York, NY: Marcel Dekker, Inc.

Peiris, J. S. M., Chu, C. M., Cheng, V. C. C., Chan, K. S., Hung, I. F. N., Poon, L. L. M., et al. (2003). Clinical progression and viral load in a community outbreak of coronavirus-associated SARS pneumonia: A prospective study. The Lancet, 361, 1767-1772.

SARS Epidemiology Working Group. (2003). Consensus document on the epidemiology of severe acute respiratory syndrome (SARS). http://www.who.int/csr/sars/en/WHOconsensus.pdf. Accessed 2 November 2004

Sobsey, M. D., \& Meschke, J. S. (2003). Virus survival in the environment with special attention to survival in sewage droplets and other environmental media of fecal or respiratory origin. Report for the World Health Organization, Geneva, Switzerland, p. 70.

Wang, L. F., Shi, Z., Zhang, S., Field, H., Daszak, P., \& Eaton, B. T. (2006). Review of bats and SARS. Emerging Infectious Diseases, 12(12), 1834-1840.

Wang, X. W., Li, J. S., Guo, T. K., Zhen, B., Kong, Q. X., Yi, B., et al. (2005a). Excretion and detection of SARS coronavirus and its nucleic acid from digestive system. World Journal of Gastroenterology, 11(28), 4390-4395.

Wang, X. W., Li, J. S., Jin, M., Zhen, B., Kong, Q. X., Song, N., et al. (2005b). Study on resistance of severe acute respiratory syndrome-associated coronavirus. Journal of Virological Methods, 126, 171-177. 